\title{
Hanna Banaś
}

\section{Między sacrum a profanum: relacje wolności religijnej i wolności sztuki w orzecznictwie $\mathrm{ETPCz}$}

\section{Prawne uregulowania obu wolności}

Wraz z rozwojem prawa międzynarodowego, a w jego ramach praw człowieka, kolejne obszary życia i działalności ludzkiej obejmowane były ochroną prawną - czy to na gruncie konwencji międzynarodowych, czy różnych aktów prawa krajowego. Do jednej z takich dziedzin można zaliczyć wolność sztuki, która, stanowiąc przejaw aktywności artystycznej jednostki, podlega ochronie. Nie zawsze jednak jest objęta ochroną bezpośrednio w danym akcie prawnym - wtedy też rodzi się najwięcej kontrowersji co do zastosowania regulacji.

Niniejszy artykuł dotyczyć będzie problematyki interpretacji przepisów odnoszących się do wolności artystycznej z jednej strony, a trudności w stosowaniu ich w praktyce, z drugiej. Całość zagadnienia została ujęta w kontekście wolności religijnej. Najpełniejsze orzecznictwo w tym zakresie (jakkolwiek i tak niewystarczające) posiada Europejski Trybunał Praw Człowieka (ETPCz), dlatego to na nim opierać się będą rozważania obejmujące tematyką prawo europejskie ${ }^{2}$. Za główny przykład posłużą dwa kluczowe wyroki: Wingrove przeciwko Wielkiej Brytanii i Otto Preminger Institute przeciwko Austrii ${ }^{3}$.

1 Konkretniej - w kontekście problemów ochrony praw jednostki, gdy dochodzi do styku wolności myśli, sumienia i wyznania (w dalszej części określanej jako wolność religijna) oraz wolności sztuki (zamiennie nazywanej wolnością artystyczną).

2 Przez „prawo europejskie” rozumie się tu zarówno prawo Unii Europejskiej (UE), jak i prawo innych regionalnych organizacji międzynarodowych (np. Rady Europy) oraz prawo obowiązujące w państwach europejskich. Zamiennikiem stosowanym w tekście dla określenia prawa UE jest „prawo unijne” (lub „prawo wspólnotowe”, jeśli odnosi się do aktów prawnych sprzed wejścia w życie Traktatu Lizbońskiego).

3 Orzeczenia Otto Preminger Institute v. Austria z dnia 20 września 1994 roku (skarga nr 13470/87; dalej: OPI) i Wingrove v. The United Kingdom z dnia 25 listopada 1996 roku (skarga nr 17419/90; dalej: Wingrove). Oba wyroki znajdują się w bazie orzeczeń HUDOC Europejskiego Trybunału Praw Człowieka (wersja angielska i francuska). 
Rozpatrywanie problematyki należy zacząć od określenia, czym w istocie jest wolność religijna i wolność sztuki. Jest to o tyle trudne, że w żadnym z aktów prawnych na poziomie międzynarodowym definicja legalna nie została zawarta - co oznacza, że brak jest wspólnego, precyzyjnego spojrzenia na te wolności; brak spojrzenia, które pozwoliłoby stworzyć pewną i konkretną podstawę rozstrzygania. W większości kwestie te pozostawione zostały do rozstrzygnięcia sądom krajowym.

Rozważania na temat wolności religijnej są łatwiejsze do podjęcia niż te dotyczące wolności artystycznej. Wolność religijna została bowiem wprost ujęta w większości konwencji dotyczących w sposób ogólny praw człowieka - takich jak Powszechna Deklaracja Praw Człowieka ${ }^{4}$, Międzynarodowy Pakt Praw Obywatelskich i Politycznych ${ }^{5}$, ale i europejska Konwencja o Ochronie Praw Człowieka i Podstawowych Wolności ${ }^{6}$ czy inne konwencje o regionalnym zasięgu'

W tym miejscu warto zacytować art. 9. Konwencji dotyczący wolności myśli, sumienia i wyznania:

\section{Artyku1 9.}

1. Każdy ma prawo do wolności myśli, sumienia i wyznania; prawo to obejmuje wolność zmiany wyznania lub przekonań oraz wolność uzewnętrzniania indywidualnie lub wspólnie $z$ innymi, publicznie lub prywatnie, swego wyznania lub przekonań przez uprawianie kultu, nauczanie, praktykowanie i czynności rytualne.

2. Wolność uzewnętrzniania wyznania lub przekonań może podlegać jedynie takim ograniczeniom, które są przewidziane przez ustawę i konieczne w społeczeństwie demokratycznym z uwagi na interesy bezpieczeństwa publicznego, ochronę porządku publicznego, zdrowia i moralności lub ochronę praw i wolności innych osób. ${ }^{8}$

Jak zostało wskazane w cytowanym artykule, każdy - bez wyjątku - ma prawo do wolności religijnej. W zakres tej wolności wchodzi również nieposiadanie żadnego wyznania, a także posiadanie poglądów niezwiązanych z konkretną religią (na przykład wegetarianizm, pacyfizm). Poglądy te można wyrażać w dowolny sposób, acz z pewnymi

4 Powszechna Deklaracja Praw Cztowieka, przyjęta na Zgromadzeniu Ogólnym ONZ dnia 10 grudnia 1948 roku.

5 Międzynarodowy Pakt Praw Obywatelskich i Policznych z dn. 16.12.1966, wszedł w życie 23.03.1976 r. (UNTS tom 999 s. 171 i tom 1057 s. 407); wersja angielska.

6 Konwencja o Ochronie Praw Cztowieka i Podstawowych Wolności, sporządzona w Rzymie 4 listopada 1950 r.w ramach Rady Europy (Dz. U. z 1993r. Nr 61, poz. 284 z późniejszymi zmianami). Dalej: Konwencja.

7 Np. Afrykańska Karta Praw Człowieka i Ludów , art. 8; (zrewidowana) Arabska Karta Praw Cztowieka, art. 25 i 30; Amerykańska Konwencja Praw Cztowieka, art. 12.

8 Artykuł cytowany $\mathrm{z}$ oficjalnego polskiego przekładu; zapisy pozostałych aktów prawnych są identyczne albo bardzo zbliżone do cytowanego, dlatego nie ma potrzeby przytaczania kolejnych. 
ograniczeniami ${ }^{9}$. Celem szczegółowego zapoznania się z samą problematyką wolności religijnej warto sięgnąć po komentarze do tego artykułu i jemu podobnych ${ }^{10}$.

Nieco inaczej na gruncie prawa międzynarodowego przedstawia się kwestia wolności sztuki i jej regulacji. Nie zawsze w aktach dotyczących praw człowieka wolność artystyczna jest wprost wskazana. Zazwyczaj wyprowadzana zostaje z szerszej (pod względem zakresu) wolności wypowiedzi ${ }^{11}$.

I tak, jako powolujący wprost wolność sztuki, można wskazać art. 15 ust.1. Międzynarodowego Paktu Praw Gospodarczych, Społecznych i Kulturalnych (MPPGiK) ${ }^{12}$, który stanowi:

Państwa Strony niniejszego Paktu uznają prawo każdego do:

a) Udziału w życiu kulturalnym;

b) Korzystania z osiągnięć postępu naukowego i jego zastosowań;

c) Korzystania $\mathrm{z}$ ochrony interesów moralnych i materialnych, wynikających z wszelkiej twórczości naukowej, literackiej i artystycznej, której jest autorem.

Jak słusznie zauważa w swoim komentarzu Andrzej Wróbel ${ }^{13}$, poprzez takie sformułowanie przepisu, literat - paradoksalnie - przestaje być artystą, a zostaje wpisany w zupełnie odrębną kategorię. Dodatkowo w tym samym artykule państwa zobowiązały się do poszanowania swobody, która jest konieczna, aby móc prowadzić badania naukowe oraz realizować działalność artystyczną (twórczą) ${ }^{14}$. Z uwagi na status ONZ na arenie międzynarodowej MPPGiK mógłby stanowić dobrą podstawę do stworzenia konkretnej regulacji dotyczącej wolności artystycznej, jej zakresu i ograniczeńn ${ }^{15}$.

9 Wolność słowa (ekspresji) została ujęta w art. 10; o jego treści poniżej.

10 Zainteresowanym dokładniejszym zgłębieniem tematyki, można polecić np. Konwencja o Ochronie Praw Cztowieka i Podstawowych Wolności. Tom I. Komentarz do artykutów 1-18, red. L. Garlicki Warszawa 2010, komentarz do art. 9, nb 13 i następne.

11 Po porównaniu kilku aktów prawnych stwierdzić można, że w żadnej z przywoływanych wcześniej (patrz przypisy 4-7) konwencji międzynarodowych nie ma wprost zapewnionych gwarancji wolności sztuki (wolności artystycznej). Zazwyczaj, jeśli zaistnieje taka potrzeba, wyprowadza się to prawo $z$ wolności wypowiedzi, przyjmując, że sztuka też jest swego rodzaju wyrażeniem poglądów.

12 Międzynarodowy Pakt Praw Gospodarczych, Spotecznych i Kulturalnych z dnia 19 grudnia 1966 r. (Dz. U. z 1977 r. Nr 38, poz. 169).

13 A. Wróbel, Karta Praw Podstawowych. Komentarz, Warszawa 2013, art. 13, nb 1.

14 Zob. MPPGiK, art. 15 ust. 3.

15 Prawie wszystkie państwa świata podpisały i ratyfikowały; źródło: https://treaties.un.org/Pages/ViewDetails.aspx?src=TREATY\&mtdsg_no=IV-3\&chapter $=4 \& l a n g=e n$. 
$\mathrm{Na}$ gruncie ściśle europejskim ${ }^{16}$ wprost wyrażona wolność artystyczna pojawia się jedynie w art. 13. Karty Praw Podstawowych Unii Europejskiej ${ }^{17}$ i to ujęta dość lapidarnie:

Artykuł 13.

Wolność sztuki i nauki.

Sztuka i badania naukowe są wolne od ograniczeń. Wolność akademicka jest szanowana.

Sama Konwencja milczy jednak na temat wolności sztuki, ograniczając się do art. 10, zapewniającego wolność wypowiedzi. ${ }^{18}$

W tym kontekście trudno jest znaleźć wspólne, międzynarodowe ramy prawne dotyczące relacji sztuki i religii oraz określić wspólną linię orzeczniczą sądów krajowych poszczególnych państw. Taką rolę powinien pełnić Trybunał, ale - co zostanie podniesione w dalszej części tekstu - nie zawsze staje on na wysokości zadania.

Powodem trudności w pogodzeniu tych dwóch praw - wolności religijnej i wolności artystycznej - może być również geneza współczesnej sztuki. Jak zauważa Andrzej Draguła ${ }^{19}$ w swoich rozważaniach na temat historycznych relacji obu wolności: „sztuka chce przejąc funkcje zarezerwowane dotychczas dla religii, wywołując u odbiorcy reakcje analogiczne do tych, które charakteryzują ludzi wierzących w relacji do obrazów świętych" ${ }^{20}$. Jest to spojrzenie niepozbawione racji, zwłaszcza jeśli weźmie się pod uwagę reakcje wierzących odbiorców sztuki na dzieła, w których wykorzystywane są motywy religijne - oraz artystów, którzy chętnie z nich korzystają, by wywołać choćby chwilowe oburzenie $^{21}$. Draguła stawia również tezę, że „być może wizerunki religijne wcale nie są sztuką, a w związku z tym trzeba by stosować inne kryteria dotyczące korzystania z ni-

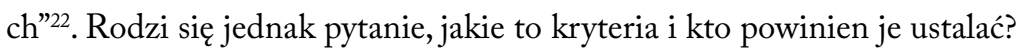

16 Przez wyrażenie "grunt ściśle europejski” na potrzeby niniejszego artykułu należy rozumieć prawodawstwo regionalne obowiązujące na terytorium Europy, będące jednakże aktami prawa międzynarodowego (nie praw poszczególnych państw, w których konstytucjach bezpośrednie odniesienie może się pojawiać).

17 Karta Praw Podstawowych Unii Europejskiej (Dz. UE. 2010/C, 83/02).

18 Szerzej ta kwestia zostaje rozwinięta w dalszej części.

19 A.Draguła, „Prawo wtasności” do religii w sztuce [w:] Swoboda wypowiedzi w dziatalności artystycznej, red. D.Bychawska-Siniarska, D. Głowacka, Warszawa 2014.

20 Ibidem, s. 37.

21 Draguła podnosi, że tak naprawdę artyści ci wcale nie zaprzeczają „mocy obrazów”, wręcz przeciwnie - zdają sobie z niej sprawę i wykorzystują to; muszą w tę moc wierzyć, inaczej by tego nie robili. Różnica polega tylko na tym, że o ile wierzący są „, na tak”, artyści wykorzystujący w sposób szokujący motywy religijne są niejako „na nie”. Por. A. Draguła, op.cit., s.35.

22 Ibidem, s. 31. 
Między sacrum a profanum... 73

\section{Sprawa Otto Preminger Institut przeciwko Austrii}

W zakresie wolności artystycznej w nawiązaniu do wolności religijnej ETPCz wydał kilka orzeczeń, spośród których Otto Preminger Institut jest jednym z pierwszych i najważniejszych.

Sprawa dotyczyła prywatnego stowarzyszenia, które zaplanowało cykl sześciu pokazów filmu „Das Liebeskonzil”Wernera Schroetera. Wszystkie zostały zapowiedziane na godzinę 22.00, poza jednym, które miało mieć miejsce o godzinie 16.00. Osób poniżej siedemnastego roku życia nie dopuszczano do oglądania seansu. Sam film opowiadał historię Oskara Panizzy, potępionego dramaturga, który napisał sztukę „Das Liebeskonzil” [„Rada Niebieska” - przyp. aut.], w której przedstawił Boga jako zniedołężniałego starca, Jezusa jako upośledzonego umysłowo młodzieńca, a Marię Pannę jako kobietę lekkich obyczajów. Cała trójka oraz diabeł (który został przedstawiony jako inteligentny manipulator) planuje zesłanie kary na rozwiązłą ludzkość, czego efektem jest choroba o objawach syfilisu. Sztuka została zakazana w Niemczech, poza nimi jednakże była rozpowszechniana ${ }^{23}$.

Władze Austrii zakazały wyświetlania tego filmu, żaden z pokazów się nie odbył. Jedyna kopia, jaką OPI posiadało, została skonfiskowana. Stowarzyszenie przegrało wszystkie sprawy przed sądami krajowymi, wniosło więc skargę do Strasburga. Od tego czasu zostały wystawione dwie sztuki teatralne na podstawie oryginalnego dramatu, po jednej z nich również postawiono zarzuty kilku osobom ${ }^{24}$.

Komisja, oceniając skargę, stwierdziła naruszenie art. 10 Konwencji ${ }^{25}$ - głosami dziewięć do pięciu w odniesieniu do przejęcia filmu i głosami trzynaście do jednego w odniesieniu do zarządzenia jego przepadku ${ }^{26}$. Jak podaje Ireneusz C. Kamiński, zwrócono „uwagę na satyryczny charakter filmu, wymagający zawsze dystansu” "27. Uchylono się jednak od odpowiedzi na pytanie, czy ograniczenie zastosowane przez Austrię zostało podjęte dla ochrony moralności publicznej, co pozwalałoby na przyznanie znacznej swobody oceny władzom krajowym ${ }^{28}$.

Trybunał musiał zbadać, czy ingerencja państwa była zasadna i zgodna $\mathrm{z}$ prawem. W tym celu postawił trzy pytania: o to, czy została ona przewidziana prawem, czy po-

23 Vid. OPI, $\S 9-10, \S \S 20-22$.

24 Vid. ibidem, $\S \S 11-19$.

25 Art. 10 gwarantuje wolność wyrażania poglądów: „1. Każdy ma prawo do wolności wyrażania opinii. Prawo to obejmuje wolność posiadania poglądów oraz otrzymywania i przekazywania informacji i idei bez ingerencji władz publicznych i bez względu na granice państwowe. Niniejszy przepis nie wyklucza prawa Państw do poddania procedurze zezwoleń przedsiębiorstw radiowych, telewizyjnych lub kinematograficznych".

26 OPI, $\S \S 31-32$.

27 I. C. Kamiński, Ograniczenia swobody wypowiedzi dopuszczalne w Europejskiej Konwencji Praw Cztowieka. Analiza krytyczna, Warszawa 2010, rozdział VII, pkt. 3.2. Dostęp z bazy prawniczej LEX.

28 Vid. ibidem oraz OPI, §63. 
stawiony cel był legitymowany oraz czy ingerencja ta była konieczna w demokratycznym społeczeństwie.

\section{Czy ingerencja była przewidziana prawem?}

Nad tą kwestią Trybunał nie pochylał się zbyt szczegółowo. Stwierdził jedynie, że w pierwszej kolejności to władze państwa są powołane do interpretowania prawa krajowego. Sądy w Innsbrucku musiały wyznaczyć równowagę między prawem wolności artystycznej a prawem do poszanowania wierzeń religijnych ${ }^{29}$.

\section{Czy istniał legitymowany cel?}

Rozstrzygając tę kwestię, Trybunał przywołał orzeczenie w sprawie Kokkinakis przeciwko Grecjij ${ }^{30}$, w którym wskazal, że wolność religijna jest jednym z fundamentów demokratycznego społeczeństwa i istotnym elementem budujących tożsamość wierzących i ich koncepcję życia. Wskazywał dalej, że ci, którzy wybrali jakąś religię, niezależnie od tego, czy należą do większości, czy nie, nie mogą racjonalnie oczekiwać, że pozostaną poza wszelką krytyką. Muszą tolerować i akceptować przeczenie ich wierzeniom; nawet propagandę wrogich doktryn. Jednakże sposób, w jaki są prezentowane poglądy, może angażować odpowiedzialność państwa, jaką jest zapewnienie pokojowego korzystania z praw gwarantowanych w art. 9. Poszanowanie uczuć religijnych z art. 9.może zostać uznane za niedopełnione $\mathrm{z}$ uwagi na prowokacyjne portretowanie obiektów czci religijnej; co więcej, może zostać to uznane za naruszenie w złej wierze ducha tolerancji, który jest cechą demokratycznych społeczeństw ${ }^{31}$. Tym samym Trybunał uznał, że nałożone ograniczenia służyły osiągnięciu zgodnego z Konwencją celu, jakim była przede wszystkim ochrona praw innych osób ${ }^{32}$.

\section{Czy zajęcie i przepadek były „niezbędne w demokratycznym społeczeństwie”?}

Badając tę kwestię, ETPCz w pierwszej kolejności przywołał ogólne zasady mające zastosowanie w tej dziedzinie. Przede wszystkim Trybunał wskazał na obowiązek unikania tak jak to tylko możliwe wyrażeń, które są obraźliwe dla innych i tym samym naruszają prawa tych osób. Tym bardziej jest to niewskazane, jeśli nie przybiera formy debaty publicznej i nie zapewnia dalszego postępu w sprawach ludzkich. Niekiedy jednak, z uwagi na niestosowanie się do powyższych regul, zachodzi konieczność interwencji państwa -

29 Vid. ibidem, §45.

30 Orzeczenie to jest uznawane za przełomowe w odniesieniu do rozstrzygnięć ze sfery wolności religijnej. Cf. OPI, §47.

31 OPI, §47.

32 Ibidem, §48. 
należy pamiętać jednakże o tym, że środki muszą pozostać proporcjonalne do celu,jakie państwo chce osiągnąc ${ }^{33}$.

Warto mieć również na względzie, że w tak delikatnych i niedookreślonych kwestiach, jaką jest między innymi moralność, nie jest możliwe utworzenie wspólnej europejskiej koncepcji dotyczącej znaczenia religii w społeczeństwie; nawet w obrębie jednego kraju moga się one bowiem różnić. $Z$ tego powodu nie sposób ustalić, co stanowi dopuszczalną ingerencję państwa w wolność wypowiedzi jednostki, jeśli wypowiedź ta jest kierowana przeciwko uczuciom religijnym. Państwa posiadają zatem w tej sferze margines oceny, nie jest on jednak nieograniczony - idzie bowiem w parze z nadzorem Trybunału. Niezbędność jakiegokolwiek ograniczenia musi być zatem wystarczająco przekonująco umocowana ${ }^{34}$.

W dalszej części Trybunał przystąpił do zastosowania powyższych zasad w niniejszej sprawie. Rząd argumentował zastosowane środki tym, że religia pełni ważną rolę w życiu mieszkańców, z których większość to katolicy. Istniała zatem nagląca potrzeba społeczna ochrony porządku publicznego ${ }^{35}$, a sądy w Innsbrucku nie przekroczyły marginesu oceny. Skarżący podnosił wprawdzie, że dopełnił zasad bezpieczeństwa mających na celu niedopuszczenie do kontaktu z dziełem osób, które mogłyby poczuć się urażone, ale nie przekonało to Trybunału ${ }^{36}$. Zauważył on, że mimo wskazanych zabezpieczeń, film był szeroko reklamowany, co uczyniło go wystarczająco publicznym, by spowodować naruszenie uczuć religijnych. Tym samym ETPCz przyznał rację państwu, nie dopatrując się naruszenia obowiązków konwencyjnych ${ }^{37}$.

Sprawa budziła sporo kontrowersji, nie powinno zatem dziwić, że nie wszyscy sędziowie byli zgodni co do sentencji. Troje z nich - Palm, Pekkanen i Makarczyk - złożyło wspólne zdanie odrębne, z którego warto przytoczyć najważniejsze punkty. Przede wszystkim, sędziowie wskazali na istotę art. 10, gwarantującego wolność wypowiedzi i brak racji jego istnienia w momencie, gdy wolność ta realizowana jest jedynie w sytuacji zgodności z ogólnie akceptowaną opinią ${ }^{38}$. Została również poruszona kwestia marginesu oceny państwa; kontestujący uznali bowiem, że to nie do władz należeć powinna decyzja o tym, czy dana wypowiedź przyczynia się do rozwoju ${ }^{39}$. Nie udzielają jednak odpowiedzi na pytanie, kto w takim razie miałby tej oceny dokonywać. A jeśli nikt, to czy oznacza to całkowitą bezkarność w sytuacji wypowiedzi skrajnie rażących i naruszających prawa innych? Czy wolność słowa powinna iść tak daleko, że nie byłaby niczym ograniczona? Czy zatem jedynymi kryteriami ograniczeń są te zawarte w art. $10 \$ 2$ i obraza uczuć religijnych nie może mieć nigdzie miejsca?

33 Ibidem, $\$ 49$.

34 Ibidem, §50.

35 Poprzez zajęcie taśmy z filmem i zarządzenie jej przepadku.

36 OPI, §52-53.

37 Ibidem, pkt.3 sentencji wyroku.

38 Vid. Pkt. 3 zdania odrębnego.

39 Ibidem, pkt. 4. 
Na większość tych pytań próżno szukać odpowiedzi w zdaniu odrębnym, wskazane zostało natomiast zagrożenie płynące $\mathrm{z}$ zastosowania ochrony interesu silnej grupy społecznej - wtedy przedsiębranie takich prewencyjnych działań, jak miało to miejsce w niniejszej sprawie, może być szkodliwe dla tolerancji, od której zależy demokratyczne społeczeństwo ${ }^{40}$. Sędziowie stanęli na stanowisku, że Konwencja nie gwarantuje ochrony uczuć religijnych; uznali przy tym, że prawa tego nie można wyprowadzać $z$ wolności religijnej. Jednakże zgodzili się, że do pewnego stopnia ochrona uczuć religijnych członków społeczeństwa może być „legitymowana” w rozumieniu art. 10 i że może być to „konieczne w demokratycznym społeczeństwie”, by takie ograniczenia nałożyć ${ }^{41}$.

Konkludując, sędziowie stwierdzili, że jakkolwiek zgadzają się, że do obrazy uczuć religijnych doszło, to uznają zastosowane środki za nieproporcjonalne - państwo miało do dyspozycji inne możliwości niż zajęcie filmu i orzeczenie jego przepadku ${ }^{42}$.

W doktrynie sprawa Otto Preminger Institut jest bardzo często przywoływana w odniesieniu do wolności sztuki. Podobnie jednak jak w przypadku sędziów wyrokujących w sprawie, i tutaj głosy są podzielone. Dominika Bychawska-Siniarska uważa, że „wolność artystyczna jest stosunkowo słabo chroniona przez Europejski Trybunał Praw Człowieka (...), w szczególności w zderzeniu z ochroną moralności czy uczuć religijnych" ${ }^{33}$. Z tego powodu krytykuje omawiane orzeczenie, jak również i wyrok w sprawie Wingrove, wskazując, że Trybunał „w sposób dużo bardziej restrykcyjny (...) podchodzi do spraw, w których ingerencja w swobodę działalności artystycznej uzasadniona była ochroną uczuć religijnych" ${ }^{44}$. Nie komentuje jednak w żaden sposób orzeczenia, ograniczając się jedynie do cytowanego stwierdzenia i zarysowania sprawy.

W nieco większym zakresie do wyroku odnosi się Anthony Lester, który krytykuje szeroki margines uznania przyznany państwom i stwierdza, że:

skala ustępstw europejskich sędziów wobec cenzury krajowej oznacza, że ETPCz nie jest w stanie wyartykułować właściwych kryteriów tam, gdzie swoboda wypowiedzi pozostaje w konflikcie z powszechnymi i głęboko zakorzenionymi lokalnymi przekonaniami na temat dobrego smaku, przyzwoitości publicznej i osobistej wiary. ${ }^{45}$

40 Ibidem.

41 Ibidem, pkt. 6 -7.

42 Ibidem, pkt. $10-11$.

43 D. Bychawska-Siniarska, Wolnośc artystyczna w orzecznictwie Europejskiego Trybunatu Praw Człowieka [w:] Swoboda wypowiedzi w dziatalności artystycznej, red. D.Bychawska-Siniarska, D. Głowacka, Warszawa 2014, s. 59.

44 Ibidem, s.63.

45 A. Lester, Sztuka dla sztuki-komentarz do orzecznictwa Europejskiego Trybunatu Praw Cztowieka w sprawach z zakresu wolności wypowiedzi artystycznej [w:] Swoboda wypowiedzi w dziatalności artystycznej, red. D.Bychawska-Siniarska, D. Głowacka, Warszawa 2014, s.80. 
Uważa, że tym samym przypisywana jest większa waga wolności religijnej niż wolności artystycznej ${ }^{46}$. W takim momencie nasuwa się pytanie, czy w takim razie sztuka posiada jakieś granice, a jeśli tak - gdzie należy je wyznaczyć. Czy w demokratycznym państwie prawo jednostki może stać ponad prawami wielu jednostek, większości społeczeństwa? To prowadzi do rozważań o kontratypie sztuki, który stanowi równie kontrowersyjne zagadnienie ${ }^{47}$. Również Kamiński podaje, że wyrok spotkał się z krytyką doktryny. Najmocniejszą według niego wyraził Patrick Wachsman, który nazywa go godnym pożałowania już w tytule komentarza. W samej treści określa orzeczenie ,jako mające groźne następstwa, bo dokonuje ono relatywizacji swobody wypowiedzi i przekształca skargę dotyczącą art. 10 EKPC w dyskusję o obronie swobód religijnych”48.

\section{Sprawa Wingrove przeciwko Wielkiej Brytanii}

To druga z kluczowych spraw ze styku wolności religijnej i wolności sztuki. Skarga ta została wniesiona w odniesieniu do art.10 (a nie art. 9), jako że skarżącym (a tym samym poszkodowanym) był producent i dystrybutor filmu pornograficznego, a nie osoba, której uczucia religijne mogłyby zostać naruszone.

Nigel Wingrove, reżyser filmowy, napisał scenopis dla krótkometrażowej pracy wideo zatytułowanej „Wizje Ekstazy”49. Według twierdzeń autora, film ten był inspirowany życiem św. Teresy z Avila ${ }^{50}$. Akcja dzieła koncentruje się na młodej aktorce ubranej w zakonny habit, w dalszej części pojawia się również jej nagie alter ego oraz figura Jezusa Chrystusa przybitego do krzyża; całość ma wydźwięk bardzo seksualny, jakkolwiek sam stosunek nie został przedstawiony ${ }^{51}$. Autor nie poczynił również żadnej próby, aby wyjaśnić swoje inspiracje i historyczne tło ${ }^{52}$; zgłosił jednakże dzieło do odpowiedniej Rady, by uzyskać pozwolenie na jego rozprowadzanie ${ }^{53}$.

Rada nie wydała zezwolenia, wskazując na kilka ważnych aspektów sytuacji Wingrove. Przede wszystkim prawo karne Wielkiej Brytanii przewidywało karę za tego typu

\section{Vid. ibidem.}

47 Zdania na ten temat w polskiej doktrynie są bardzo podzielone; nie istnieje formalnie żadna instytucja pozwalająca na bezkarność z uwagi na działalność artystyczną, natomiast część doktryny mocno popiera takie rozwiązanie.

48 I. C. Kamiński, Wolność myśli, sumienia i wyznania a swoboda wypowiedzi [w:] Prawne granice wolności sumienia i wyznania, red. R.Wieruszewski, M.Wyrzykowski, L.Kondratiewa-Bryzik, Warszawa 2012, s. 226.

49 Zob. Wingrove, $\$ 8$.

50 Ibidem; św. Teresa z Avila była karmelitańską zakonnicą i mistyczką, żyjącą w XVI wieku, która doświadczała silnie ekstatycznych wizji Chrystusa.

51 Ibidem, 9 .

52 Ibidem, §10; na końcu filmu pojawia się jedynie obsada.

53 Ibidem, $§ \S 11$ - 12. Rada ta to British Board of Film Classification; chodziło o nadanie odpowiedniej kategorii wiekowej. 
czyn klasyfikowany jako bluźnierstwo. Ponieważ reżyser zasięgnął porady prawników, wiedział - albo co najmniej mógł przewidzieć - że jego praca może nie spotkać się z akceptacją jako naruszająca prawo. Sam fakt zgłoszenia tego do Rady świadczył o tym, że Wingrove mógł mieć wątpliwości co do legalności swojego dzieła. Poza tym, jak wskazała w swojej decyzji Rada, „gdyby męską figurą nie był Chrystus, problem by nie powstał" 54 .

Ponieważ artysta odwołał się od tej decyzji do wyższej instancji, Rada, wnosząc formalną odpowiedź na zarzuty, wskazała dodatkowo, że:

w Wielkiej Brytanii przestępstwo bluźnierstwa jest popełniane, jeśli praca wideo traktuje przedmiot religijny [przedmiot kultu - przyp. aut.] (w szczególności Boga, Chrystusa lub Biblię) w taki sposób, który jest obliczony (to jest, związany, nie zamierzony) na oburzenie tych, którzy mają zrozumienie dla [...] chrześcijańskiej historii i etyki. ${ }^{55}$

Oznacza to, że autor nie musi posiadać intencji oburzenia innych, a jedynie jego dzieło musi być w jakiś sposób związane z czczonym przez wyznawców danej religii przedmiotem kultu. Dotyczy to jednakże tylko chrześcijan ${ }^{56}$. Wingrove nie otrzymał zatem zezwolenia na rozprowadzanie swojego filmu.

Ostatecznie sprawa została wniesiona do Europejskiej Komisji Praw Człowieka. Komisja uznała skargę za dopuszczalną, stwierdzając większością czternastu do dwóch głosów, że doszło do naruszenia art. 10. Konwencji.

Podobnie jak w sprawie OPI, Trybunał pochylił się nad zasadnością ingerencji państwa w prawa jednostki i zbadał trzy kryteria, których spełnienie usprawiedliwiałoby ograniczenie praw jednostki na gruncie art. 10 ust. $2^{57}$. Tym samym sędziowie musieli po raz kolejny odpowiedzieć sobie na pytania o to, czy ingerencja była „przewidziana przez

54 Tłumaczenie własne Autorki; ang. If the male figure were not Christ, the problem would not arise. Zob. Wingrove, §13. Takie stanowisko Rady zastanawia, gdyż wskazuje na to, że nie byłoby karane naruszenie innych świętości chrześcijan (poza Bogiem).

55 Por. Wingrove..., $\$ 15$.

56 Zarzut nierównego traktowania innych religii i „faworyzowanie” chrześcijan, zwłaszcza Kościoła anglikańskiego, skarżący podniósł przed Trybunałem i zostanie on wspomniany w dalszej części artykułu.

57 Ust. 2 wspomnianego artykułu brzmi: „2. Korzystanie z tych wolności pociągających za sobą obowiązki i odpowiedzialność może podlegać takim wymogom formalnym, warunkom, ograniczeniom i sankcjom, jakie są przewidziane przez ustawę i niezbędne w społeczeństwie demokratycznym w interesie bezpieczeństwa państwowego, integralności terytorialnej lub bezpieczeństwa publicznego ze względu na konieczność zapobieżenia zakłóceniu porządku lub przestępstwu, z uwagi na ochronę zdrowia i moralności, ochronę dobrego imienia i praw innych osób oraz ze względu na zapobieżenie ujawnieniu informacji poufnych lub na zagwarantowanie powagi i bezstronności władzy sądowej.”. 
prawo" ${ }^{58}$, czy realizowany cel był legitymowany oraz czy ingerencja ta była „konieczna w demokratycznym społeczeństwie”. Każde z tych pytań również w tej sprawie należy pokrótce rozważyć.

\section{Czy ingerencja była „przewidziana przez prawo”?}

Skarżący podnosil, że prawo dotyczące bluźnierstwa pozostaje zbyt niepewne i trudno było przewidzieć, że akurat w tym konkretnym przypadku to na nim skupią się zarzuty ${ }^{59}$. Rząd zakwestionował tę skargę, stwierdzając, że cechą powszechną większości praw i systemów prawnych jest to, że przy orzekaniu sąd może dojść do różnych konkluzji, nawet stosując to samo prawo do tych samych faktów ${ }^{60}$. Komisja zaś, biorąc pod uwagę udzieloną skarżącemu pomoc prawną, uznała, że mógł przewidzieć restrykcje, jakim został poddany ${ }^{61}$.

Trybunał stwierdził, że - zgodnie $z$ jego orzecznictwem - istotne dla sprawy prawo krajowe powinno zostać sformułowane w wystarczająco precyzyjny sposób, by konsekwencje były możliwe do przewidzenia ${ }^{62}$. Przyznał również, że Rada działała w zakresie swoich kompetencji oraz że przestępstwo bluźnierstwa ze swej istoty uniemożliwia stworzenie precyzyjnej definicji legalnej. Tym samym, to do władz krajowych należy ocenienie, czy dana sprawa mieści się w zakresie akceptowanej definicji przestępstwa ${ }^{63}$. Do oceny tego kryterium na korzyść rządu przyczynił się również sam skarżący, który, idąc za wskazaniem swojego radcy, nie wszczął procedury sądowej, przypuszczając, że jego dzieło może spełniać znamiona przestępstwa. $Z$ uwagi na powyższe, Trybunał stwierdził, że restrykcje, z jakimi spotkał się skarżący, zostały nałożone zgodnie z prawem ${ }^{64}$.

\section{Czy realizowany przez władze cel był celem legitymowanym?}

Skarżący kwestionował argument rządu dotyczący praw innych obywateli, wskazując, że istnieje realne prawo do nie bycia obrażanym - a nie hipotetyczne prawo do unikania niepokojów, zwłaszcza w perspektywie tego, że inni ludzie oglądali to wideo bez zszokowania $^{65}$. W tym kontekście skarżący podnosił również, że ograniczenia na niego nałożone są oparte na prawie dyskryminującym, które obejmuje swoim zakresem jedynie część wierzących ${ }^{66}$. Rząd z kolei powołał się na sprawę Otto-Preminger-Institut przeciwko Austrii, gdzie Trybunał przyznał, że poszanowanie dla uczuć ludzi wierzących może

58 Dokładniej, prescribed by law.

59 Vid.. Wingrove, \$37.

60 Ibidem, §38.

61 Ibidem, $\$ 39$.

62 Ibidem, $\$ 40$.

63 Ibidem, $\S \S 41-42$.

64 Ibidem, $\$ \$ 43-44$.

65 Ibidem, §45.

66 Wingrove odnosił to do chrześcijan, zwłaszcza wyznania anglikańskiego, gdyż brytyjskie prawo tylko im przyznawało tego typu ochronę. 
doprowadzić do legalnego ograniczenia publikacji dzieła, które w sposób prowokacyjny portretuje obiekt czci religijnej ${ }^{67}$. Komisja przyznała również, że zostało to poczynione dla ochrony obywateli i ich uczuć religijnych.

Trybunał zgodził się z Komisją, stwierdzając, że cel ten niewątpliwie mieści się znaczeniu art. 10. ust. 2., a także jest całkowicie zgodny z celem ochrony zapewnianym przez art. 9. dla wolności religijnej ${ }^{68}$. Odrzucony został również argument skarżącego dotyczący dyskryminującego prawa bluźnierstwa; Trybunał uznał, że nie jest jego rolą orzekanie in abstracto $\mathrm{w}$ sprawie zgodności prawa krajowego z Konwencją ${ }^{69}$. Fakt, że prawo o bluźnierstwie nie traktuje w sposób równy wszystkich wyznań, nie umniejsza jednak legitymizacji celu ${ }^{70}$.

\section{Czy ingerencja ta była „konieczna w demokratycznym społeczeństwie”?}

Rozpatrując tę kwestię, Trybunał przypomniał w pierwszej kolejności, że wolność wypowiedzi tworzy jedną z istotnych podstaw demokratycznego społeczeństwa; realizacja tej wolności jednakże niesie ze sobą obowiązki i odpowiedzialność ${ }^{71}$. Test, który musi zostać zdany, by uznać za legalną ingerencję państwa, nazywany jest „testem niezbędności”. Po raz kolejny Trybunał przywołał również zasadę, wedle której państwa cieszą się pewnym marginesem swobody oceny i to do nich należy rozstrzygnięcie, czy dane środki zastosowane w konkretnej sytuacji były wymagane. Ten margines oceny nie jest jednak nieograniczony, a ponadto, nie pozostaje bez kontroli - jak zostało wspomniane, ETPCz sprawdza, czy państwa nie nadużywają swoich praw. By wydać ostateczny wyrok w sprawie zgodności działań państwa z Konwencją, należy jeszcze sprawdzić, czy istniała „nagląca potrzeba społeczna” oraz czy działania te były „proporcjonalne do zamierzonego celu"72. Trybunał skupił się w swoich rozważaniach na kwestii bluźnierstwa, konkludując, że - jakkolwiek już coraz rzadsze - stosowanie zapisów penalizujących zachowania określane jako bluźniercze nie jest samo w sobie niepotrzebne w demokratycznym społeczeństwie; zwłaszcza gdy wciąż brak wspólnych standardów europejskich regulujących te kwestie ${ }^{73}$.

67 Wingrove, $\$ 46$.

68 Ibidem, §48.

69 O ile zrozumiałe wydaje się być takie rozumowanie Trybunału, to - mimo wszystko - może ono budzić sprzeciw. Nawet jeśli Trybunał powołany jest do orzekania w danej, konkretnej sprawie, to wyznacza jednak pewien poziom i kierunek orzekania w kolejnych, podobnych sprawach - nie tylko w ramach samej Rady Europy, ale również na poziomie krajowym. Brak chociażby krótkiego komentarza (ale jednak dłuższego niż jedno zdanie) rozczarowuje.

70 Wingrove, $\$ 50$.

71 Ibidem, $\$ 52$.

$72 \mathrm{Vid}$. \$53 i n. Skarżący oczywiście utrzymywal, że taka potrzeba nie istniała i wideo mogło być rozprowadzane przy zachowaniu pewnych środków ostrożności i odpowiednim jego zabezpieczeniu. Komisja zgodziła się ze skarżącym.

73 Ibidem, §57; Trybunał przywołał również omówione już orzeczenie OPI, §49. 
Trybunał wskazał również, że angielskie prawo nie zabrania krytykowania chrześcijaństwa ani wyrażania poglądów jemu wrogich. Istotne jest jednak, w jaki sposób te treści i poglądy są prezentowane. Dodatkowo, po obejrzeniu filmu, sędziowie uznali, że decyzje władz krajowych nie mogą zostać uznane za arbitralne ${ }^{74}$. Co więcej, chodziło głównie o możliwość rozpowszechniania dzieła - jak wskazał Trybunał, gdyby tylko trafiło do legalnej dystrybucji, mogłoby być rozprowadzone na wiele innych sposobów, niekoniecznie zgodnych z prawem. Tym samym byłoby niemożliwością utrzymać nad całym procesem całkowitą kontrolę. I to władze krajowe są na lepszej pozycji, by określić, jaki wpływ miałoby dopuszczenie tego wideo do obrotu, niż ETPC $z^{75}$.

Trybunał przyznał rację stronie rządowej, nie stwierdzając naruszenia art. 10. Do wyroku zostały złożone zdania odrębne sędziów Bernhardta, Pettiti, de Meyer i Lohmusa ${ }^{76}$. Dystrybucja filmu została całkowicie zakazana. Dopiero kilka lat temu zakaz zdjęto i zakwalifikowano film jako przeznaczony dla odbiorców powyżej 18. roku życia. Obecnie film jest już nawet dostępny w Internecie.

Również i ta sprawa spotkała się z krytyką w doktrynie, choć już nie tak ostrą jak ta względem Otto Preminger Institute. Bychowska-Siniarska stwierdziła wprawdzie, że „podejście Trybunału do spraw dotyczących bluźnierstwa jest szeroko krytykowane na szczeblu międzynarodowym”, jak również, że „komentatorzy uznają, iż Trybunał, powinien odstąpić od tak szerokiego marginesu swobody uznania sądów krajowych w tych sprawach”, nie przywołała jednak żadnych nazwisk, trudno więc określić skalę krytyki ${ }^{77}$.

Bardziej konkretne stanowisko zajmuje Kamiński. Według niego Trybunał jest niekonsekwentny w swoich orzeczeniach, bowiem:

sędziowie zadawalają się strukturalnymi zabezpieczeniami przed pochopnym kwalifikowaniem działania jako bluźnierczego, ale równocześnie akceptują ograniczenie bluźnierstwa do obrazy religii chrześcijańskiej. Zatem nawet po osiągnięciu krytycznego progu wypowiedź dotykająca niechrześcijan nie zostanie zakwalifikowana jako bluźniercza. ${ }^{78}$

74 Ibidem, $\$ \S 60-61$.

75 Ibidem, $\$ 63$.

$76 \mathrm{Na}$ uwagę zasługuje zdanie odrębne sędziego Pettiti, który słusznie zauważa, że sprawę tę należałoby rozpatrywać również pod kątem zakazu dyskryminacji (art.14), jednakże taki postulat nie został przez skarżącego wniesiony. Co więcej, według sędziego art. 9 nie ma tutaj zastosowania, a całość wyroku należałoby oprzeć na art. 10. Nie można również automatycznie usprawiedliwiać zakazu dystrybucji.

77 D. Bychowska-Siniarska, op.cit., s. 64. A.Lester, który także powoływał omawianą sprawę, nie opatrzył jej żadnym komentarzem (vid. A.Lester, op.cit., s. 79-80).

78 I. C. Kamiński, Ograniczenia...., 4.1. 
Tym samym nie da się uzasadnić ingerencji jako koniecznej, nawet przy założeniu szerokiego marginesu oceny władz krajowych ${ }^{79}$.

\section{Konkluzje}

Po tylu latach orzekania Trybunału, sprawy wolności sztuki w odniesieniu do wolności religijnej nadal nie sposób wskazać zbyt wielu wyroków, na których można by się oprzeć, przy tworzeniu konkretnego stanowiska strasburskiego sądu. Wprawdzie w tych dwóch sprawach $\mathrm{ETPC} z$ przyznał rację stronie państwowej, nie można tego jednak uznać za normę i pewne wypracowane standardy. Przykładowo, w odniesieniu do satyry czy karykatury, z góry należy założyć przesadę i zniekształcenie, a to wymaga dystansu. Ochrona takich wypowiedzi jednostki zdaje się być według Wróbla absolutyzowana ${ }^{80}$.

W orzecznictwie Trybunału można wyróżnić niejako trzy testy, którymi ten posługuje się przy wyrokowaniu. Pierwszy z nich, wywodzący się ze sprawy Müller i inni przeciwko $S z$ wajcarii ${ }^{81}$, to test sposobu prezentacji dzieła. Ważne jest, w jaki sposób dzieło zostało zaprezentowane, jak szerokiej publiczności i czy powzięto odpowiednie kroki, by nie dopuścić do kontaktu $z$ dziełem osób, których uczucia mogłyby zostać zranione. Sprawa ta dotyczyła konfiskaty obrazów, które uznano za obsceniczne, gdyż przedstawiały ludzką seksualność w obraźliwych formach (na przykład zoofilii). Sąd krajowy skazał artystę na karę grzywny oraz zarządził konfiskatę dzieł. Komisja przyznała Müllerowi rację, natomiast Trybunał, podobnie jak w sprawie OPI czy Wingrove, zachowawczo stanął po stronie państwa „podkreślając, że twórczość wiąże się także z odpowiedzialnością, oraz powołując się na szeroki margines swobody uznania w odniesieniu do potrzeby ochrony

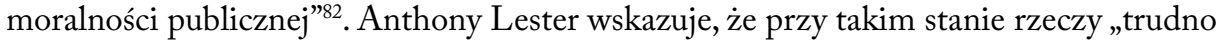
wyobrazić sobie sprawę, w której artysta mógłby liczyć na skuteczny europejski nadzór sądowy" ${ }^{83}$. Być może jest to przesadzona teza, ale biorąc pod uwagę przywoływane orzeczenia - niekoniecznie bezzasadna obawa.

Drugi test, pojawiający się w omawianej już sprawie OPI, dotyczy nieobrażania i wartości dzieła. Trzeci zaś wspólnego europejskiego standardu (którego niestety w zakresie moralności i religii nadal brak $)^{84}$.

Zastrzeżenia odnośnie do omówionych rozstrzygnięć dotyczą pochylenia się przez ETPCz nad definicjami i stosowanymi kryteriami. Trybunał trzyma się ściśle wyznaczonych ram, niejako sprawdzając tylko, czy sądy krajowe w odpowiedni sposób dopełniły

79 Vid. ibidem.

80 Vid. A. Wróbel, op. cit., art. 13, nb 13.

81 Müller i inni przeciwko Szwajcarii z dnia 24 maja 1988 roku (skarga nr 10737/84).

82 A.Lester, op.cit., s.79.

83 Ibidem.

84 Tak np. I .C. Kamiński, Glosa do wyroku ETPC z dnia 25 stycznia 2007r., 68354/01. Swoboda autora wypowiedzi będacej satyrą lub karykaturq., pkt. 3.1 . 
formalności przy wyrokowaniu. Nie jest to niezgodne z prawem - ale mimo wszystko rozczarowuje brak refleksji nad pewnymi kwestiami. Jakkolwiek Trybunał nie jest powołany do tworzenia prawa, wyznacza poprzez swoje orzecznictwo nowe trendy i kierunki, wskazując, czym należy się przede wszystkim kierować przy wyrokowaniu w danej sprawie. $\mathrm{Na}$ jego orzeczeniach sądy krajowe w pewien sposób opierają również swoje rozstrzygnięcia. Trybunał ma możliwość stworzenia standardów w zakresie praw człowieka - brak chociażby próby zastanowienia się nad jakimś konkretnym przypadkiem może być oznaką rozsądku i rozwagi, ale równie dobrze może wynikać z konformizmu.

Trzeba jednak przyznać, że nie zawsze tak się dzieje. W tym przypadku uznanie wolności artystycznej za przejaw wolności słowa (co pozwala rozszerzyć na nią ochronę gwarantowaną w art.10.) czy uczuć religijnych jako zasługujących na objęcie zakresem art. 9. (w pewnych przypadkach) pokazuje, że mimo wszystko Trybunał szuka rozwiązań najbardziej odpowiadających rzeczywistości.

Przykładem mogą być nowsze orzeczenia, w których $\mathrm{ETPC}$ próbuje odejść od ustalonej linii orzeczniczej. Pierwsze z nich, I. A. przeciwko Turcji $i^{85}$, dotyczyło skazania autora książki napisanej w stylu powieści, która została zakwalifikowana przez sądy krajowe jako atak na „Boga, Religię, Proroka i Świętą Księge”. Niewielką przewagą głosów (cztery do trzech) Trybunał nie dopatrzył się naruszenia art. 10. ${ }^{86}$. Według sędziów wyrażających zdanie odrębne wyroki w sprawach Otto Preminger Institute oraz Wingrove nie były prawidłowe i należało dokonać ich przeglądu, przełamując dotychczasową linię orzeczniczą. Należy jednak zauważyć, że sprawa $I$. $A$. odróżnia się od powoływanych wcześniej dwóch podstawowych spraw - choćby z uwagi na znacznie mniejszy zasięg działania (tylko 2 tysiące egzemplarzy), a tym samym wpływ na społeczeństwo. Sędziom nie chodzi jednak o szukanie racji rozróżnienia, co może być kwestią drugorzędną, a po prostu o odejście od dotychczasowego orzecznictwa, które oceniają jako błędne ${ }^{87}$.

Drugą sprawą, którą warto przywołać w kontekście prób odchodzenia Trybunału od tez zawartych w swoich wcześniejszych wyrokach, jest Vereinigung Bildender Künstler przeciwko Austrii ${ }^{88}$. Dotyczyła ona otwartej wystawy pod tytułem „Stulecie wolności artystycznej”, a konkretniej dzieła tam wystawianego - obrazu Apokalipsa autorstwa Ottona Mühla. Przedstawiał on różne osoby publiczne (niektóre $\mathrm{z}$ nich związane były z religią - na przykład Matka Teresa z Kalkuty) uczestniczące w seksualnej orgii. W tym przypadku przewaga głosów również była niewielka - stosunkiem czterech do trzech sędziowie zdecydowali, że ingerencja państwa pogwałciła prawa jednostki z art. 10. Co zaskakujące, w żadnym z tych wyroków nie pojawił się argument moralności publicznej. W VBK skarżony był zakaz eksponowania płótna, gdyż sądy krajowe stwierdziły, iż

85 I. A. przeciwko Rosji z 13 września 2005r. (skarga nr 42571/98).

86 I. C. Kamiński, Ograniczenia..., pkt 6.1.

87 Ibidem.

88 Vereinigung Bildender Künstler przeciwko Austrii z 25 stycznia 2007 (skarga nr 68354/01). 
zostało naruszone dobre imię jednej z przedstawionych na obrazie postaci ${ }^{89}$. Kamiński uważa, że „kluczowe jest (...) zakwalifikowanie dzieła jako satyry i karykatury, które zakładają przesadę i zniekształcenie dokonane przez twórcę”, jednakże „wyrok w austriackiej sprawie zdaje się czynić ochronę satyry absolutną. Jest ponadto wątpliwe, czy rozstrzygniecie daje się spójnie wpisać w dotychczasowe orzecznictwo" ${ }^{90}$. Przypuszcza on ponadto, że gdyby Trybunał skupił się na kwestii obrazy moralności publicznej, zamiast dobrego imienia jednej z przedstawionych osób, wyrok byłby inny (pozytywny dla państwa ${ }^{91}$. Wciąż jednak brak przystającego do współczesnych standardów, jasnego stanowiska Trybunału, który w sposób kompleksowy zająłby się kwestią nie tylko wolności artystycznej jako takiej, ale i jej styku z wolnością myśli, sumienia i wyznania.

$\mathrm{Na}$ gruncie polskim nie brak opracowań w tym zakresie, dotyczą one jednak przede wszystkim przypadków krajowych (takich jak na przykład sprawa Nergala czy „Pasji” Nieznalskiej), odnosząc się do polskich regulacji, nie skupiając się na orzecznictwie ETPCz (albo poprzestając na przywołaniu dwóch omówionych w niniejszym artykule wyroków). Echem orzecznictwa strasburskiego na rodzimym gruncie są rozważania o możliwości zastosowania kontratypu wolności artystycznej, co jednak stanowi materię na odrębny artykuł.

To, o czym trzeba przede wszystkim pamiętać, zastanawiając się nad relacją wolności sztuki i wolności religijnej - państwu pozostawiony jest margines oceny, ale pod nadzorem Trybunału; najistotniejszą zaś kwestią jest znalezienie równowagi między interesem społeczności i jednostki, żadne bowiem prawo czy wolność nie może być stawiane ponad inną.

\section{SUMMARY}

Between sacrum and profanum: the relationship of religious freedom and the freedom of art in the jurisprudence of the ECHR

Formerly, art was closely connected to religion. Nowadays, art is such a far-reaching, controversial phenomenon, that the recipient no longer knows what he is looking at. Religion (as an aim) is a great example. It applies to the most intimate sphere of the individual's life and it is difficult to legally regulate this issue. There is no definition of art, nor of religion, which is sufficiently precise to be a basis for judgments. The European Court of Human Rights has partly dealt with this matter in its judgments but this is still not enough to solve the problem.

KeYwords: human rights, freedom of religion, freedom of art, European Court of $\mathrm{Hu}-$ man Rights

89 I. C.Kamiński, Ograniczenia..., pkt. 6.1.

90 Ibidem.

91 Ibidem. 